\title{
PENGARUH KEJELASAN SASARAN ANGGARAN DAN EVALUASI ANGGARAN TERHADAP PENGAWASAN ANGGARAN (STUDI EMPIRIS PADA KABUPATEN KAMPAR)
}

\author{
Aras Aira.SE.,M.Ak
}

\begin{abstract}
The research soughtly to test the effect of budget quality consisting of the budget target clarity, the budget evaluation on the budget supervision effectivity.. The population of the research was the members of parliament serving for the period of 2009-2014. The data were the collected using a quaestionnaire to 43 members of parliament, however only 34 quaestionnaires were returned.The result revealed that the budget target clarity, the budget evaluation significantly effected the supervision effectivity.
\end{abstract}

Key Words : Budget target clarity, budget evaluation and budget supervision.

\section{A. Pendahuluan}

Berlakunya Undang-Undang tentang Otonomi Daerah serta Pengelolaan dan Pertanggungjawaban Pengawasan Keuangan Daerah memberikan dampak positif bagi kedudukan, fungsi dan hak-hak DPRD, anggota DPRD atau yang sering disebut dewan akan lebih aktif dalam menyampaikan aspirasi masyarakat. Selain itu, adanya otonomi daerah merupakan tuntutan bagi pemerintah daerah dalam menciptakan good governance yaitu dengan mengutamakan akuntabilitas dan transparansi.

Kegiatan Pengawasan biasanya berkaitan dengan pengukuran prestasi atau pencapaian tujuan. Sarana yang digunakan dalam pengukuran prestasi adalah anggaran (Konntz,et al.,1984), dengan demikian kegiatan pengawasan dapat dipengaruhi oleh kualitas anggaran karena dalam proses pengawasan tersebut anggaran dibandingkan dengan informasi tentang apa yang sebenarnya terjadi (Stoner,1982). Terkait dengan masalah ini dalam penelitiannya Kennis (1979) menyimpulkan bahwa kualitas anggaran (berdasarkan 5 karakteristik anggaran : partisipasi anggaran, kejelasan sasaran, evaluasi, umpan balik dan tingkat kesulitan anggaran) berpengaruh signifikan terhadap sikap/prilaku manejer serta berpengaruh sigifikan terhadap kinerja anggaran.Dalam penelitian ini, penulis hanya menggunakan 2 variabel yang terdiri dari 2 karakteristik anggaran yang berkualitas yang dinyatakan Kennis (1979) yaitu Kejelasan sasaran anggaran dan evaluasi anggaran

Karakteristik anggaran yang pertama adalah kejelasan sasaran anggaran. Anggaran dapat dikatakan berkualitas jika sasaran anggaran dinyatakan secara jelas, pada konteks pemerintah daerah, sasaran anggaran tercakup dalam Rencana Strategik Daerah (Renstrada) dan Program Pembangunan Daerah (Propeda). Menurut Kennis (1979), adanya sasaran anggaran yang jelas akan memudahkan individu untuk menyusun target-target anggaran (jika dilihat dari sisi penyusun), dalam hal pengawasan kejelasan sasaran anggaran seharusnya mempengaruhi kinerja dewan dalam bekerja, karena sasaran yang jelas akan menunjukkan bahwa tujuan dan objek yang dilakukan pengawasan semakin jelas. Locke (1981) mengungkapkan bahwa tujuan-tujuan akan mengarahkan upaya, perhatian, persistensi, strategi-strategi dan rencana kegiatan. Sehingga tujuan yang jelas akan memberi motivasi bagi dewan 
dalam melakukan pengawasan terhadap anggaran secara efektif.

Kennis (1979) menyimpulkan bahwa kejelasan sasaran berpengaruh secara positif dan signifikan terhadap sikap dan prilaku manager terhadap anggaran, Zein (1993) hasil penelitiannya menyimpulkan bahwa kejelasan sasaran berpengaruh terhadap pengendalian, Abdullah (2004) dalam hasil penelitiannya menyimpulkan bahwa kejelasan sasaran berpengaruh terhadap akuntabilitas kinerja instansi pemerintah daerah, Arifin (2004) menyimpulkan bahwa kejelasan sasaran berpengaruh signifikan terhadap efesiensi biaya, sedangkan Halim dan Made menyimpulkan kejelasan sasaran berpengaruh terhadap efektifitas pelaksanaannya.

Karakteristik yang kedua adalah evaluasi anggaran, evaluasi anggaran adalah tindakan yang dilakukan untuk menelusuri anggaran kedepartemen yang bersangkutan dan digunakan sebagai dasar penilaian kinerja departemen, dalam pelaksanaan APBD setiap SKPD melakukan evaluasi untuk menilai kinerjanya masing-masing, apakah kinerjanya sesuai yang direncanakan atau sebaliknya untuk itu suatu anggaran harus selalu dievaluasi agar nantinya APBD dapat dilaksanakan sesuai yang direncanakan.

Evaluasi anggaran pada dasarnya membandingkan antara anggaran dengan pelaksanaan sehingga dapat ditentukan penyimpangan yang terjadi. Penyimpangan ini akan digunakan sebagai dasar untuk mengukur efisiensi serta penilaian prestasi. Anggaran yang digunakan dalam mengevaluasi prestasi cenderung mempengaruhi perilaku dan prestasi para pelakunya. Menurut Brownell et.al dalam Robinson (1978) evaluasi yang bersifat punitive dapat menyebabkan rendahnya motivasi, sebaliknya evaluasi yang bersifat supportive dapat menghasilkan sikap dan tingkah laku positif.
Kennis (1979) menyimpulkan bahwa evaluasi anggaran berpengaruh secara positif dan signifikan terhadap sikap dan prilaku manager terhadap anggaran, Zein (1993) hasil penelitiannya menyimpulkan bahwa evaluasi anggaran berpengaruh terhadap pengendalian, Abdullah (2004) dalam hasil penelitiannya menyimpulkan bahwa evaluasi anggaran berpengaruh terhadap akuntabilitas kinerja instansi pemerintah daerah, Arifin (2004) menyimpulkan evaluasi anggaran berpengaruh signifikan terhadap efesiensi biaya, sedangkan Halim dan Made menyimpulkan evaluasi anggaran berpengaruh terhadap efektivitas pelaksanaannya.

\section{B.TELAAH PUSTAKA \\ 1. Pengertian Pengawasan}

Keputusan presiden RI No.74 tahun 2001 pasal 1 ayat 6 menyebutkan bahwa pengawasan pemerintah daerah adalah proses kegiatan yang ditujukan untuk menjamin agar pemerintah daerah berjalan sesuai dengan rencana dan ketentuan peraturan perundangundangan yang berlaku, selanjutnya juga disebutkan bahwa pengawasan penyelenggaraan pemerintah daerah terdiri atas pengawasan fungsional, pengawasan legislatif dan pengawasan masyarakat.

Peraturan pemerintah No.105 tahun 2000 (tentang pengelolan dan pertanggungjawaban keuangan Negara ) pasal 40 menyebutkan bahwa pengawasan atas pelaksanaan APBD dilakuakan oleh DPRD. Dalam penjelasan pasal ini dinyatakan bahwa pengawasan yang dimaksud dalam ayat ini adalah bukan pemeriksaan tetapi pengawasan yang mengarah untuk mencapai pencapaian sasaran yang telah ditetapkan APBD.

Dalam UU No.32 tahun 2004 pasal 42 ayat 1 disebutkan bahwa DPRD diberikan hak untuk meminta laporan keterangan pertanggungjawaban kepala daerah dalam 
penyelenggraan pemerintah daerah. Mengenai hak meminta pertanggungfjawaban kepala daerah merupakan hak strategis bagi DPRD dalam menjalankan fungsi pengawasan. Dengan demikian sesuai dengan paradigm baru berkembang saat ini, DPRD mempunyai posisi, tugas, dan fungsi yang penting dan semakin luas dalam pengewasan keuangan daerah, oleh sebab itu sebagai lembaga legislatif DPRD harus benar-benar melakukan fungsi pengawasan tersebut agar pelayanan public yang telah direncanakan dapat dilaksanakan sesuai dengan perda yang telah ditetapkan, perlu diingat pengawasan yang dilakukan DPRD sebaiknya mulai dilakukan pada tahap awal yaitu tahap perencanaan sampai dengan tahap pelaoporan.

Secara spesifik, hasil pengawasan DPRD terhadap Pemerintah Daerah ditujukan :

1. Untuk menjamin agar Pemerintah Daerah berjalan sesuai dengan rencana dan ketentuan peraturan perundang-undangan yang berlaku,

2. Untuk menjamin kemungkinan tindakan koreksi yang cepat dan tepat terhadap penyimpangan dan penyelewengan yang ditemukan dalam upaya mencegah berlanjutnya kesalahan dan atau penyimpangan,

3. Untuk menumbuhkan motivasi, memperbaiki, mengurangi dan atau meniadakan penyimpangan,

4. Untuk meyakinkan bahwa kinerja pemerintah daerah sedang atau telah mencapai tujuan dan sasaran yang telah ditetapkan. (KPK, Kajian Peran Anggota DPRD, 2005)

Melalui pengawasan tersebut, DPRD system atau sistem penanda bahaya apabila

terjadi kejanggalan atau penyimpangan dalam

proses pengelolaan tata pemerintahan daerah.

Agar Pengawasan merupakan tahap integral dengan keseluruhan tahap pada penyusunan dan pelaporan APBD, pengawasan diperlukan pada setiap tahap bukan hanya pada tahap evaluasi saja (Mardiasmo,2001).

Menurut Schermerhorn (2002) pelaksanaan pengawasan dapat dibagi atas 4 jenis yaitu :

1. Pengawasan Freeforward (pengawasan umpan didepan). Pengawasan ini dilakukan sebelum aktivitas dimulai yang bertujuan untuk menjamin kejelasan sasaran; tersedianya arahan yang memadai, ketersediaan sumber daya yang dibutuhkan dan memfokuskan pada kualiatas sumber daya.

2. Pengawasan Concurrent (pengawasan bersamaan). Pengawasan ini memfokuskan pada apa yang terjadi selama proses berjalan yang bertujuan untuk memonitor aktivitas yang sedang berjalan untuk menjamin segala sesuatu sesuai rencana dan juga mengurangi hasil yang tidak diinginkan.

3. Pengawasan feedback (pengawasan umopan balik). Pengawasan ini dilakukan setelah aktivitas dilaksanakan. Dengan tujuan untuk menyediakan informasi yang berguna untuk meningkatkan kinerja dimasa depan dan mefokuskan pada kualitas hasil.

4. Pengawasan internal-eksternal. Pengawasan internal memberikan kesempatan untuk memperbaiki diri sendiri, sedangkan pengawasan eksternal melalui supervise dan penggunaan administrasi formal. 


\section{Karakteristik Penyusunan Anggaran}

Agar manfaat dan tujuan diatas dapat tercapai, suatu anggaran menurut Kennis (1979) harus memenuhi karakteristik sebagai berikut :

\section{Kejelasan Sasaran Anggaran}

Kejelasan sasaran adalah luasnya sasaran yang dinyatakan secara jelas dan spesifik serta dimengerti oleh pihak yang bertanggung jawab terhadap pencapaiannya (Kennis,1979), sasaran anggaran yang dinyatakan secara spesifik lebih produktif dibanding dengan tidak adanya sasaran yang spesifik dan hanya akan mendorong untuk melakukan terbaik.

Menurut Kennis (1979), kejelasan sasaran anggaran merupakan sejauh mana tujuan anggaran ditetapkan secara jelas dan spesifik dengan tujuan agar anggaran tersebut dapat dimengerti oleh orang yang bertanggung jawab atas pencapaian sasaran anggaran tersebut. Oleh sebab itu sasaran anggaran pemerintah daerah harus dinyatakan secara jelas, spesifik dan dapat dimengerti oleh mereka yang bertanggung jawab untuk melaksanakannya. Locke (1968) dalam Kenis (1979) menyatakan bahwa penetapan tujuan spesifik akan lebih produktif. Hal ini akan mendorong karyawan/ Staf untuk melakukan yang terbaik bagi pencapaian tujuan yang dikehendaki sehingga berimplikasi pada peningkatan kinerja baik kinerja yang melaksanakan anggaran maupun yang mengawasi anggaran yakni anggota DPRD

2. Adanya evaluasi anggaran

Evaluasi anggaran adalah tindakan yang dilakukan untuk menelusuri anggaran kedepartemen yang bersangkutan dan digunakan sebagai dasar penilaian kinerja departemen (Kennis,1979). Evaluasi anggaran dilaksanakan dengan maksud untuk mengetahui kemungkinan adanya penyimpangan anggaran, yang digunakan untuk mengevaluasi prestasi para manajer oleh atasan, penelitian oleh Wilsch dalam Made (2004) menunjukkan bahwa adanya pengaruh yang signifikan antara evaluasi anggaran dengan kinerja manajer.

\section{Kerangka Pemikiran dan Perumusan Hipotesis Kerangka Pemikiran}

Berbeda dengan penelitian-penelitian sebelumnya yang menguji pengaruh kejelasan sasaran anggaran, evaluasi anggaran terhadap berbagai variable ditinjau dari pihak yang menyusun dan melaksanakan anggaran, maka penelitian ini mencoba untuk menguji pengaruh kejelasan sasaran anggaran terhadap variabel yang melakukan pengawasan terhadap anggaran yaitu pihak DPRD, karena itu maka karakteristik anggaran yang digunakan pada penelitian ini hanya kualitas anggaran yang diukur melalui karakteristik kejelasan sasaran anggaran, evaluasi anggaran sedangkan karakteristik partisipasi, umpan balik, dan tingkat kesulitan anggaran pengukurannya melalui pihak yang menyusun, penelitian serupa telah dilakukan oleh Robinson (2006), yang dalam penelitiannya menunjukkan bahwa kejelasan sasaran dan evaluasi anggaran berpengaruh terhadap efektifitas pengawasan keuangan daerah yang dilakukan DPRD..

Dari kerangka pemikiran di atas maka hipotesisnya adalah sebagai berikut :
HI : Kejelasan sasaran anggaran berpengaruh signifikan terhadap efektifitas pengawasan anggaran.

$\mathrm{H} 2$ : Evaluasi anggaran berpengaruh signifikan terhadap efektifitas pengawasan anggaran. 
GAMBAR 1

KERANGKA KONSEPTUAL

$$
\begin{array}{ll}
\text { X1 } & =\text { Kejelasan sasaran } \\
\text { a1 } & =\text { Konstanta } \\
\text { b1 } & =\text { Koefisien regresi }
\end{array}
$$

\section{D.Hasil Penelitian dan Pembahasan}

\section{D.1 Tingkat Pengembalian Kuesioner}

Dari 43 kuesioner yang dibagikan, hanya 34 yang bisa diolah karena ada 6 kuesioner yang tidak dikembalikan dan 3 kuesiner yang tidak lengkap.

\section{D.2 Statistik Deskriptif}

\section{C.1 Populasi dan Sampel}

Populasi adalah sekelompok orang, kejadian atau segala sesuatu yang mempunyai karakteristik tertentu (Nur Indriantoro,2002). Populasi dari penelitian ini adalah seluruh anggota DPRD Kabupaten Kampar yang berjumlah 45 orang dengan menggunakan metode sensus.

\section{C.2 Jenis dan Sumber Data}

Data yang digunakan dalam penelitian ini merupakan data primer yang diperoleh langsung melalui penyampaian kuesioner kepada responden di lingkungan DPRD Kabupaten Kampar.

\section{C.3 Pengujian Hipotesis}

Model statistik yang digunakan untuk menguji masing-masing hipotesis dalam penelitian ini:

\section{Analisis Regresi Sederhana (simple regression)}

Berdasarkan bunyi hopotesis diatas, maka untuk menguji hipotesis 1dan 2 (H1 dan H2) menggunakan regresi sederhana, persamaan regresi untuk hipotesis 1 dan 2 dapat dirumuskan sebagai berikut:

$\mathrm{Y}=$

dan 2 )

Keterangan : $\mathrm{Y} \quad=\quad$ Efektifitas

pengawasan
Tabel 1

Statistik Deskriptif Variabel Penelitian

\begin{tabular}{|c|c|c|c|c|c|}
\hline Variabel & $\mathrm{N}$ & Min & Max & Mean & $\begin{array}{c}\text { Std. } \\
\text { Deviation }\end{array}$ \\
\hline KejelasanAPBD & 34 & 19.00 & 40.00 & 30.4118 & 5.02188 \\
\hline KeakuratanAPBD & 34 & 11.00 & 25.00 & 18.0000 & 3.12371 \\
\hline EfektivitasPengawasan & 34 & 24.00 & 39.00 & 32.1471 & 3.67739 \\
\hline
\end{tabular}

Sumber : Pengolahan data primer,2011

\section{D.3 Hasil Uji Kualitas Data}

Hasil pengujian realibilitas data dapat dilihat dari tabel berikut :

\section{Tabel 2}

\section{Hasil Pengujian Realibilitas}

\begin{tabular}{|l|l|c|}
\hline No & \multicolumn{1}{|c|}{ Instrument } & $\begin{array}{c}\text { Uji realibilitas } \\
\text { (Cronbach alpha) }\end{array}$ \\
\hline 1 & Kejelasan Sasaran & 0.853 \\
\hline 2 & Keakuratan nggaran & 0.878 \\
\hline 5 & pengawasan & 0.875 \\
\hline
\end{tabular}

Sumber :pengolahan data primer,2011

Dari tabel di atas, diketahui bahwa dari hasil pengujian reliabilitas untuk semua instrumen diperoleh nilai cronbach alpha lebih besar dari 0.6 yaitu $0.754-0.878$. Hal ini berarti bahwa jawaban responden terhadap setiap pertanyaan reliable dan konsisten. Sehingga layak digunakan dalam penelitian ini. 
Tabel 3

Hasil pengujian validitas

Uji autokorelasi dilakukan dengan melihat

Durbin-Watson.penilaian dilakukan dengan membandingkan nilai Durbin-Watson dengan nilai tabel dengan tingkat signifikansi 5\%.

\begin{tabular}{|l|l|l|l|l|l|l|l|l|l|l|}
\hline \multirow{2}{*}{ Variabel } & \multicolumn{9}{|c|}{ Uji Validitas (signifikansi) } \\
\cline { 2 - 11 } & P.1 & p.2 & P.3 & P.4 & P.5 & P.6 & P.7 & P.8 & P.9 & P.10 \\
\hline Kejelasan & 0.000 & 0.000 & 0.000 & 0.000 & 0.000 & 0.000 & 0.000 & 0.000 & - & - \\
\hline Evaluasi & 0.000 & 0.000 & 0.000 & 0.000 & 0.000 & 0.000 & 0.000 & 0.000 & - & - \\
\hline Pengwasn & 0.000 & 0.000 & 0.000 & 0.000 & 0.001 & 0.000 & 0.000 & 0.000 & - & - \\
\hline
\end{tabular}

Sumber : Pengolahan data primer,2011

Dengan melihat tabel diatas dapat dilihat bahwa masing-masing pertanyaan pada setiap variabel memiliki signifikansi yang berkisar antara 0.000-0.001 kecil dari 0.05 hal ini berarti bahwa disimpulkan bahwa masing-masing item pertanyaan valid, sehingga bisa digunakan untuk mengukur setiap variabel. Hal ini berarti bahwa setiap pertanyaan mampu mengukur apa yang diinginkan.

\section{D.5 Hasil Uji Asumsi Klasik}

\section{Hasil Uji Multikolinieritas}

Uji multikolinieritas bertujuan untuk menguji apakah model regresi ditemukan adanya korelasi antar variabel bebas (independen). Model regresi yang baik seharusnya tidak terjadi korelasi diantara variabel independen (Ghozali, 2005).

\section{Tabel 4}

\section{Hasil Pengujian Multikolinieritas}

\begin{tabular}{|c|c|c|c|}
\hline Variabel & VIF & Tolerance & Keterangan \\
\hline $\begin{array}{c}\text { Kejelasan sasaran } \\
\text { anggaran }\end{array}$ & 3.782 & .264 & Tidak ada multikolinieritas \\
\hline Evaluasi anggaran & 2.755 & .363 & Tidak ada multikolinieritas \\
\hline
\end{tabular}

Sumber : Pengolahan data primer,2011

Dari hasil pengujian diatas dapat dilihat bahwa tidak ada satu variabel pun yang memiliki nilai Tolerance < dari 0.10 yaitu berada antara nilai 0.264-0.363 yang berarti tidak ada korelasi antara variabel independen.

\section{Hasil Uji Autokorelasi}

Tabel 5

Hasil Uji Autokorelasi

\begin{tabular}{|c|c|c|}
\hline NO & MODEL REGRESI & DURBIN-WATSON \\
\hline 1 & X1 terhadap Y & 1.751 \\
\hline 2 & X2 terhadap Y & 2.075 \\
\hline
\end{tabular}

Sumber : Pengolahan data primer,2011

Dari hasil pengolahan diatas, nilai hasil uji dibandingkan dengan tabel dengan menggunakan nilai signifikansi $5 \%$, dengan jumlah sampel 34 (n) dan jumlah variabel independen 3, maka didapat bahwa nilai tabel (1.652) lebih kecil dari nilai DW,maka dapat disimpulkan bahwa tidak terjadi autokorelasi.

\section{Hasil Uji Heteroskedasitisitas}

Penelitian ini menggunakan grafik Scatter plot untuk untuk mendeteksi ada tidaknya heteroskedasitisitas pada masingmasing variabel. jika terlihat bahwa titik-titik menyebar secara acak serta tersebar baik diatas mapun dibawah angka 0 pada sumbu Y, maka tidak terdapat heteroskedastisitas. Hasil uji heteroskedastisitas adalah sebagai berikut :

\section{Gambar 2}

\section{Hasil Uji Heteroskedastisitas x1 terhadap}

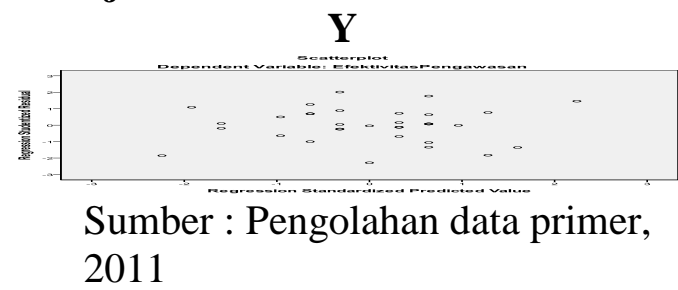




\section{Gambar 3}

Hasil Uji Heteroskedastisitas x2 terhadap

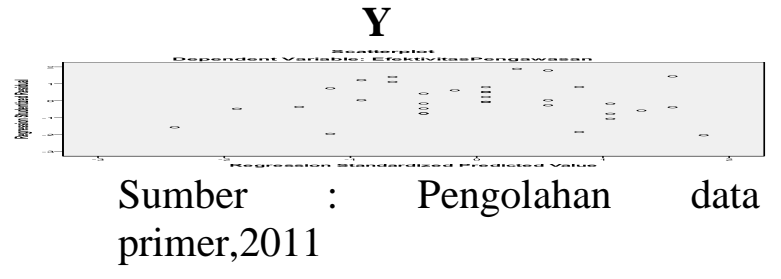

Dari gambar 2 dan 3 di atas dapat disimpulkan bahwa tidak terjadi heteroskedastisitas pada model regresi, sehingga model regresi layak dipakai untuk memprediksi efektifitas pengawasan anggaran yang dilakukan dewan berdasarkan masukan variabel kejelasan anggaran, dan pemoderasi (pengetahuan dewan).

\section{Hasil Uji Normalitas}

Tabel 6

Hasil Pengujian Normalitas

\begin{tabular}{|c|c|c|c|c|}
\hline & $\begin{array}{c}\text { Kejelasan } \\
\text { APBD }\end{array}$ & Evaluasi & Pengawasan \\
\hline \multicolumn{2}{|l|}{$\mathrm{N}$} & 34 & 34 & 34 \\
\hline \multirow{2}{*}{$\begin{array}{l}\text { Normal } \\
\text { Parameters } \\
\text { a,b }\end{array}$} & Mean & 30.4118 & 32.7059 & 32.1471 \\
\hline & $\begin{array}{l}\text { Std. } \\
\text { Deviation }\end{array}$ & 5.02188 & 4.05664 & 3.67739 \\
\hline \multirow{3}{*}{$\begin{array}{l}\text { Most } \\
\text { Extreme } \\
\text { Difference } \\
\mathrm{s}\end{array}$} & Absolute & .180 & .089 & .102 \\
\hline & Positive & .180 & .089 & .085 \\
\hline & Negative & -.131 & -.088 & -.102 \\
\hline \multicolumn{2}{|c|}{ Kolmogorov-Smirnov Z } & 1.048 & .952 & .593 \\
\hline \multicolumn{2}{|c|}{ Asymp. Sig. (2-tailed) } & .222 & .952 & .873 \\
\hline
\end{tabular}

Sumber : Pengolahan data primer,2011

Dari hasil pengujian diatas dapat dilihat bahwa asymp.sig (2-tailed) nilai probabilitas masing-masing variabel berkisar antara $0.222-0.952>0.05$, hal ini berarti bahwa residual terdistribusi normal.

\section{E. Hasil Pengujian Hipotesis dan Pembahasan}

\section{Hipotesis 1}

Tabel 7

\section{Hasil Pengujian hipotesis 1}

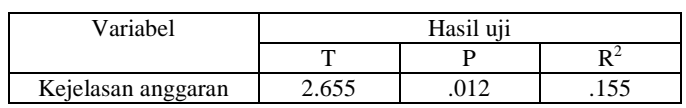

Sumber : Pengolahan Data primer,2011

Hasil regresi dari tabel 8 di atas menunjukkan bahwa kejelasan sasaran anggaran memiliki signifikansi $=0,012$ dimana lebih kecil dari Alpha $=0,05$. Dengan demikian hipotesis 1 yang menyatakan kejelasan sasaran anggaran berpengaruh terhadap efektifitas pengawasan anggaran dapat diterima. Selain itu, dari tabel di atas juga diketahui bahwa nilai koefisien determinasi yang ditunjukkan oleh nilai $\mathrm{R}^{2}$ adalah sebesar 0.155 yang berarti variabilitas pengawasan anggaran yang dapat dijelaskan oleh variabel kejelasan sasaran anggaran adalah sebesar $15.5 \%$. Sedangkan sisanya yakni $84.5 \%$ dijelaskan oleh variabel lain diluar variabel, hal ini dapat terjadi karena adanya variabel-variabel lainnya yang diduga dapat mempengaruhi hubungan antar variabel dalam model penelitian ini.

\section{Hasil Pengujian Hipotesis 2}

Tabel 8

\section{Hasil Pengujian Hipotesis 2}

\begin{tabular}{|c|c|c|c|}
\hline \multirow{2}{*}{ Variabel } & \multicolumn{3}{|c|}{ Hasil uji } \\
\cline { 2 - 4 } & $\mathrm{T}$ & $\mathrm{P}$ & $\mathrm{R}^{2}$ \\
\hline Evaluasi anggaran & 2.272 & .030 & .112 \\
\hline
\end{tabular}

Sumber : Pengolahan Data primer,2011

Dengan menggunakan ujian regresi linear sederhana, tabel di atas (tabel IV.10) memperlihatkan model persamaan regresi yang signifikan pengaruh Evaluasi terhadap Efektifitas Pengawasan, di mana nilai dengan $\mathrm{P}=0.030(p<0.05)$. hal ini berarti hipotesis 
ke 2 diterima, dengan tingkat signifikansi $=0,030<0,05$.

Hasil pengujian ini membuktikan kembali penelitian Kennis (1979), Robinson (2006), Abdullah (2004), arifin (2004), hasil penelitin menunjukkan bahwa adanya pengaruh secara segnifikan antara evaluasi anggaran dan efektifitas pengawasan. Ini berarti menunjukkan bahwa evaluasi yang dilakukan oleh SKPD terhadap anggaran turut mempengaruhi anggota dewan dalam melaksanakan fungsi pengawasan.

Selain itu, dari tabel di atas juga diketahui bahwa nilai koefisien determinasi yang ditunjukkan oleh nilai $\mathrm{R}^{2}$ adalah sebesar 0.112 yang berarti variabilitas pengawasan anggaran yang dapat dijelaskan oleh variabel kejelasan sasaran anggaran adalah sebesar $11.2 \%$. Sedangkan sisanya yakni $88.8 \%$ dijelaskan oleh variabel lain diluar variabel yang diteliti, hal ini dapat terjadi karena adanya variabel-variabel lainnya yang diduga dapat mempengaruhi hubungan antar variabel dalam model penelitian ini.

\section{E.Penutup}

\section{Kesimpulan}

Hasil pengujian terhadap hipotesis 1 menunjukkan bahwa adanya pengaruh signifikan antara kejelasan sasaran dengan efektifitas pengawasan yang dilakukan dewan.. Hasil pengujian terhadap hipotesis 2 menunjukkan bahwa adanya pengaruh signifikan antara evaluasi anggaran dengan efektifitas pengawasan yang dilakukan dewan

Masih terbatasnya populasi dan sampel yang diambil dalam penelitian ini, sehingga untuk menjeneralisasi hasil penelitian ini harus mempertimbangkan banyak faktor atau asumsi-asumsi yang lainnya.

\section{Saran}

Penelitian ini perlu diuji kembali dengan populasi yang lebih besar,dengan memperluas daerah penelitian dengan cakupan DPRD yang ada pada 1 provinsi atau bahkan jika memungkinkan anggota DPRD seluruh kabupaten yang ada.

Untuk penelitian selanjutnya perlu adanya penambahan variabel-variabel lain seperti aturan perundang-undang, kebijakan transparansi dan akuntabilitas. baik dan lebih akurat.

\section{DAFTAR PUSTAKA}

Arifin, Johan. 2007. Pengaruh Karaktersitik Gaya penyusunan Anggaran terhadap efesiensi biaya. Jurnal akuntansi dan bisnis. Vol. 9 No1, Januari. Hal 23-35

Hilmi Abdullah. 2004. Pengaruh Kejelasan Sasaran Anggaran, Pengendalian Akuntansi, dan Sistem Pelaporan terhadap Akuntabilitas Kinerja Instansi Pemerintah pada Kabupaten dan Kota di Daerah Istimewa Yogyakarta. Tesis Program Pasca Sarjana Magister Sains Universitas Gadjah Mada (tidak dipublikasikan).

Kenis, Izzetin. 1979. Effects of Budgetary Goal Characteristics on Managerial Attitudes and Performanc. The Accounting Review. Vol. LIV, No.4, October. pp. 707-721

Koontz, Harold et al. 1984. Principles of Management. McGraw-Hill. Inc.

KPK.2005. Kajian Peran Anggota DPRD.

Lock E.K, Shaw LM, Saari, Garry, 1981. Goal Setting and Task Performance: 1969-1980 . Psychological Bulletin, P. 1969-1980

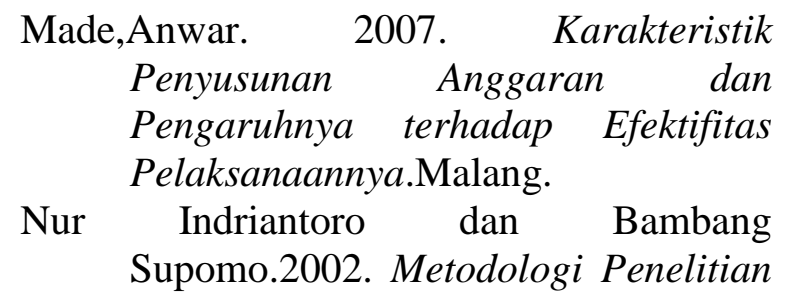


Bisnis untuk Manajemen dan Akuntansi, BPFE Yogyakarta.

Undang-Undang

Republik Indonesia No. 32 tahun 2004 tentang Pemerintahan Daerah. Depertemen Dalam Negeri Republik Indonesia. . Peraturan Pemerintah No. 105 tahun 2000 tentang Pengelolaan dan Pertanggungjawaban Keuangan daerah. Depertemen Dalam Negeri Republik Indonesia.

Keputusan Presiden No. 74 tahun 2001 tentang Tata Cara Pengawasan Penyelenggaraan Pemerintah Daerah. Depertemen Dalam NegeriRepublik Indonesia.

Keputusan Menteri Dalam Negeri No. 29 tahun 2002 tentang Pedoman Pengurusan, Pertanggungjawaban dan Pengawasan Keuangan daerah. Depertemen Dalam Negeri Republik Indonesia.

Robinson.2006. Pengaruh kualitas Anggaran terhadap efektifitas pengawasan keuangan daerah : dengan Pengetahuan Dewan sebagai Variable Moderating. Tesis Pasca Sarjana UNDIP. Semarang. Tidak Dipublikasikan.

Schermerhorn,jhon

R.2001.Management, Willey.

Schiff, M., dan A.Y Lewin. 1970. The Impact of People on Budgets. The Accounting Review. April. pp. 259268.

Stoner, James A.F. 1982. Management 2nd Edition. Prentice-Hall

Witono, Banu. 2003. Optimalisasi Peran DPRD dalam pengawasan keuangan daerah,jurnal akuntansi dan keuangan, vol. 2:151-168 